\title{
Phytochemical Action of White Mulberry Extracts against Three Important Stored Grain Pests
}

\author{
Z. R. Sabuj, A. Khatun, M. Abdullah, D. M. Badruddoza, H. Ali, N. Islam* \\ Department of Zoology, Rajshahi University, Crop Protection and Toxicology Laboratory, \\ Rajshahi-6205, Bangladesh
}

Received 15 May 2017, accepted in final revised form 26 September 2017

\begin{abstract}
Petroleum ether (Pet. ether), $\mathrm{CHCl}_{3}$ and $\mathrm{CH}_{3} \mathrm{OH}$ extracts of white mulberry were subjected to dose-mortality tests against Callosobruchus chinensis (L.), Sitophilus oryzae (L.) and Tribolium castaneum (Hbst.). Pet. ether extract of leaves against $C$. chinensis, S. oryzae and T. castaneum provided $\mathrm{LD}_{50} 9.16,5.06,3.79,2.81,2.06,1.55,1.32,1.38 \mathrm{mg} / \mathrm{g} ; 17.6,12.9$, $11.3,82.4,83.5,9.47,8.73,8.61 \mathrm{mg} / \mathrm{g}$ and $0.93,0.826,0.691,0.623,0.567,0.532,0.525$ $\mathrm{mg} / \mathrm{cm}^{2}$ after $0.5,6,12,24,36,48,60,72 \mathrm{~h}$ of exposures respectively. Against $C$. chinensis Pet. ether extract of root and stem bark gave $\mathrm{LD}_{50} 28.3,20.7$, 18.4, 16.9, 14.4, 13.6, 13.3, $13.3 \mathrm{mg} / \mathrm{g}$ and $86.3,228.9,177,109,61.0,21.8,0.999,15 \mathrm{mg} / \mathrm{g}$ after $0.5,6,12,24,36,48$, $60,72 \mathrm{~h}$ of exposures respectively. $\mathrm{CH}_{3} \mathrm{OH}$ extracts of leaves offered $\mathrm{LD}_{50} 21.5,20.4,17$, $16.2,15.6,14.7 \mathrm{mg} / \mathrm{g}$ against $C$. chinensis; $5.4,14.7,13.7,11,10.9,9.46,9.10 \mathrm{mg} / \mathrm{g}$ against S. oryzae; and $3.804,3.429,3.284,2.736,2.441,2.311,2.264 \mathrm{mg} / \mathrm{cm}^{2}$ against $T$. castaneum after $6,12,24,36,48,60,72$ h of exposures respectively. Against $S$. oryzae $\mathrm{CH}_{3} \mathrm{OH}$ extract of root and $\mathrm{CHCl}_{3}$ of stem bark gave $\mathrm{LD}_{50} 19.5,19.1,17.5,16.7,16.2,15.8,15.9 \mathrm{mg} / \mathrm{g}$ and $9.77,9.44,7.71,6.56,5.94,5.39,5.4 \mathrm{mg} / \mathrm{g}$ after $6,12,24,36,48,60,72 \mathrm{~h}$ of exposures respectively. However, $\mathrm{CHCl}_{3}$ extract of leaves and root didn't show mortality.
\end{abstract}

Keywords: Dose-mortality; White mulberry; Callosobruchus chinensis; Sitophilus oryzae; Tribolium castaneum.

(C) 2017 JSR Publications. ISSN: 2070-0237 (Print); 2070-0245 (Online). All rights reserved. doi: http://dx.doi.org/10.3329/jsr.v9i4.32589 $\quad$ J. Sci. Res. 9 (4), 359-366 (2017)

\section{Introduction}

White mulberry is a fast-growing monoecious shrub or a medium sized tree with a cylindrical stem and rough, brown, vertically fissured bark, up to $35 \mathrm{~m}$ high and $1.8 \mathrm{~m}$ in girth. The scientific name of white mulberry is Morus alba L. Leaves are variable in size and shape, usually 5 to $7.5 \mathrm{~cm}$ long, often deeply lobed, margins serrate or crenate-serrate, apex acute or shortly acuminate, base chordate or truncate; 3 basal nerves forked near the margins. Flowers are inconspicuous and greenish; male spikes (catkins) are broad,

\footnotetext{
*Corresponding author: $\underline{\mathrm{n} \_ \text {islamm@yahoo.com }}$
} 
cylindrical or ovoid, female spikes are ovoid and stalked. Fruit (syncarp) consists of many drupes enclosed in a fleshy perianth, ovoid or subglobose, up to $5 \mathrm{~cm}$ long, white to pinkish white, purple or black when ripe [1].The genus Morus contains approximately 16 members of the Family Moraceae, occurring primarily in northern temperate regions with some extension into tropical areas of Africa and the South American Andes. There are 11 species distributed widely in China [2]. White mulberry is commonly called as Chinese white mulberry, Common mulberry, Russian mulberry, Silkworm mulberry and Moral blanco [3]. White mulberry has good therapeutic activity and low toxicity and has been extensively used in conventional Chinese medicine [4]. White mulberry is reported to have neuroprotective, skin tonic, antioxidant, antihyperglycemic, antibacterial, antihypertensive and antihyperlipidemic activities [5-7].

The strategy for the present investigation was designed to carry on screening of the crude extracts of the test plant species on three important stored grain pest organisms (Callosobruchus chinensis (L.), Sitophilus oryzae (L.) and Tribolium castaneum (Hbst.)) for the detection of biological activity and keeping an option to show the extent of activity by analyzing the data statistically that read on various parameters during the course of the investigation.

Test insect C. chinensis (Family: Bruchidae) is a common species of beetle found in stored legumes [8]. The eggs are cemented to the surface of pulses and are smooth, domed structures with oval, flat bases. The larvae and pupae are normally only found in cells bored within the seeds of pulses [9]. The developmental period from egg to adult takes 2025 days $[10,11]$.

S. oryzae (rice weevil) (Family: Curculionidae) is a serious stored product pest which attacks several crops and worldwide in distribution. The adult rice weevil is a dull reddish-brown to black in colour. The larval rice weevil must complete its development inside the seed kernel. The larvae of the insect develops within the seed, hollowing it out while feeding. Total life cycle from egg to adult took 34 to 49 days with an average of 42 days at 15 to $34^{\circ} \mathrm{C}$ temperature and 58 to 89 per cent relative humidity [12].

T. castaneum (Family: Tenebrionidae) is a worldwide pest of stored products and of Indo-Australian in origin [13]. These beetles have chewing mouthparts, but do not bite or sting. The red flour beetle may elicit an allergic response [14]. The eggs are microscopic and the slender larvae are creamy yellow to light brown in colour. The adult is a small reddish-brown beetle. Total life cycle contain subsequently for egg incubation 8.8 days, larval development 22-100 days depending on temperature, pupal development 4.5 days, and for reproductive maturation 4-5 days [15].

\section{Materials and Methods}

\subsection{Collection and preparation of test materials}

White mulberry plant leaves, root and stem bark were collected from a mulberry cultivation garden just behind the Third Science Building, University of Rajshahi, 
Bangladesh in the month of April, 2016. Firstly, the plant was identified by the Department of Botany, Rajshahi University, Bangladesh where voucher specimens are kept in the Herbarium and then accordingly leaves, root and stem bark were separated while excess soil from the roots were removed without washing. Leaves, root and stem bark of the plant were then sliced and chopped into small pieces, dried under shade and powdered with the help of a hand grinder, weighed and placed in separate conical flasks to add solvents. Petroleum ether, $\mathrm{CHCl}_{3}$ and $\mathrm{CH}_{3} \mathrm{OH}$ (Merck, Germany) were used (200 $\mathrm{g} \times$ $600 \mathrm{~mL} \times 2$ times) successively each of which took for $48 \mathrm{~h}$ on a shaker. For each of the extract filtration was done by Whatman filter paper (made in USA) at $24 \mathrm{~h}$ interval in the same flask followed by evaporation until the extract was left as a scum. The extracts were then removed to glass vials and preserved in a refrigerator at $4^{\circ} \mathrm{C}$ with proper labeling.

\subsection{Collection and culture of test insects}

Test insects $C$. chinensis, $S$. oryzae and $T$. castaneum were used in insecticidal activity tests of the crude extracts from the different parts of white mulberry. These test insects were selected because they are easy cultivable and noble laboratory animals. Moreover, they are important stored grain pests in a wide variety of cereal products. All the test insects of same age were used in this investigation and were collected from the stock cultures of the Crop Protection and Toxicology Laboratory, Department of Zoology, Rajshahi University, Bangladesh.

\subsection{Dose-mortality test}

\subsubsection{Dose-mortality test on C. chinensis and S. oryzae}

For insecticidal activity test each of the three extracts were dissolved in its solvent of extraction at different concentrations to go through Ad Hoc experiments to set considerable mortality and that were considered as doses. The concentrations for Pet. ether leaves extract used in this experiment were $5,3.5,2.5,2$ and $1.5 \mathrm{mg} / \mathrm{g}$ against $C$. chinensis; 13.5, 12, 11, 10 and $9 \mathrm{mg} / \mathrm{g}$ against $S$. oryzae. The concentrations of $\mathrm{CH}_{3} \mathrm{OH}$ leaves extract were 21, 19, 17.5, 16.5 and $15 \mathrm{mg} / \mathrm{g}$ against $C$. chinensis. The concentrations for Pet. ether extract of root were 17.5, 16, 15, 13.5 and $12.5 \mathrm{mg} / \mathrm{g}$ and of stem bark were $17.5,16.5,5,13.5$ and $12 \mathrm{mg} / \mathrm{g}$ against $C$. chinensis. The concentrations for $\mathrm{CH}_{3} \mathrm{OH}$ extract of root were 19.5, 18.5, 17.5, 16.5 and $15.5 \mathrm{mg} / \mathrm{g}$ and for stem bark were $15,14,12.5,11.5$ and $10 \mathrm{mg} / \mathrm{g}$ against $S$. oryzae. Finally the concentrations for the $\mathrm{CHCl}_{3}$ extract of stem bark were 10, 9, 7.5, 6 and $5 \mathrm{mg} / \mathrm{g}$ against $S$. oryzae. For each dose preparation, $1 \mathrm{ml}$ of prepared extract using solvent was mixed with the prepared food; as the solvent was volatile it was evaporated out shortly. The actual extract present in $1 \mathrm{ml}$ mixture was calculated just dividing the value by the amount of calculated food. After drying 10 insects of the same age were released on the food in 3 replications. A control batch was also maintained with the same number of insects after preparing the food by 
applying and evaporating the solvent only. The treated insects were placed in an incubator at the same temperature as reared in stock cultures and the mortality of the insects were counted after $0.5,6,12,24,36,48,60$ and $72 \mathrm{~h}$.

\subsubsection{Dose-mortality test on T. castaneum}

The experiment for insecticidal test on $T$. castaneum is not the same as on $C$. chinensis or S. oryzae since the feeding is different. Here also the Ad Hoc experiments were set to find out the final concentrations for doses selection. The concentrations for Pet. ether leaves extract used against $T$. castaneum in this experiment were 1.086, 0.764, 0.662, 0.509 and $0.365 \mathrm{mg} / \mathrm{cm}^{2}$; while the concentrations for $\mathrm{CH}_{3} \mathrm{OH}$ extract of leaves were 1.935, 2.037, $2.292,2.547$ and $2.699 \mathrm{mg} / \mathrm{cm}^{2}$. For each application $1 \mathrm{ml}$ of the dose was dropped on a Petri dish $(50 \mathrm{~mm})$ in such a way that makes a uniform film over the Petri dish. Then the Petri dishes were air dried leaving the extraction on it. To find out the dose per square centimeter, the actual extract present in $1 \mathrm{ml}$ mixture was divided by the surface area of the Petri dish. After drying 10 insects were released (3-5 days old) in each Petri dish with three replications. A control batch was also maintained with the same number of insects. The treated beetles were then placed in the incubator at the same temperature as reared in stock cultures and the mortality was counted by hourly observation as like as $C$. chinensis and $S$. oryzae were counted.

\subsection{Statistical analysis}

The mortality (\%) was corrected using Abbott's formula [16]:

$$
P_{r}=\frac{P_{o}-P_{c}}{100-P_{c}} \times 100
$$

Where, $P_{r}=$ Corrected mortality $(\%), P_{o}=$ Observed mortality $(\%), P_{c}=$ Mortality in the control (\%). The data were then subjected to Probit analysis [17-18].

\section{Results}

\subsection{Dose mortality effects on C. chinensis}

The results of the dose mortality assays of the Pet. ether extracts of white mulberry leaves, root and stem bark; and the $\mathrm{CH}_{3} \mathrm{OH}$ extract of leaves against the adult beetles of $C$. chinensis are represented in Table 1. Highest mortality was found in Pet. ether extract of stem bark and it gave $\mathrm{LD}_{50}$ value $0.999 \mathrm{mg} / \mathrm{g}$ after $60 \mathrm{~h}$ of exposure. 
Table $1 . \mathrm{LD}_{50}$ values of white mulberry extracts against $C$. chinensis.

\begin{tabular}{cccccccccc}
\hline \multirow{2}{*}{ Solvent } & \multirow{2}{*}{ Extract } & \multicolumn{8}{c}{$\mathrm{LD}_{50} \mathrm{mg} / \mathrm{g}$ at different exposure time intervals (h) } \\
& & 0.5 & 6 & 12 & 24 & 36 & 48 & 60 & 72 \\
\hline \multirow{2}{*}{$\begin{array}{c}\text { Pet. } \\
\text { ether }\end{array}$} & Leaves & 9.16 & 5.06 & 3.79 & 2.81 & 2.06 & 1.55 & 1.32 & 1.38 \\
& Root & 28.3 & 20.7 & 18.4 & 16.9 & 14.4 & 13.6 & 13.3 & 13.3 \\
& Stem & 86.3 & 228.9 & 177 & 109 & 61.0 & 21.8 & 0.999 & 15 \\
\multirow{2}{*}{$\mathrm{CH}_{3} \mathrm{OH}$} & bark & & & & & & & & \\
& Leaves & - & 21.5 & 20.4 & 17 & 16.2 & 15.6 & 14.7 & $\begin{array}{c}\text { All } \\
\text { dead }\end{array}$ \\
\hline
\end{tabular}

\subsection{Dose mortality effects on S. oryzae}

The results of the lethal activity assays of the Pet. ether extract of white mulberry leaves; the $\mathrm{CHCl}_{3}$ extracts of stem bark; and the $\mathrm{CH}_{3} \mathrm{OH}$ extracts of root and stem bark against the adult weevils of $S$. oryzae are represented in Table 2 . The highest mortality was found in $\mathrm{CHCl}_{3}$ extract of stem bark which provided $\mathrm{LD}_{50}$ value $5.39 \mathrm{mg} / \mathrm{g}$ after $60 \mathrm{~h}$ of exposure

Table 2. $\mathrm{LD}_{50}$ values of white mulberry extracts against $S$. oryzae.

\begin{tabular}{cccccccccc}
\hline \multirow{2}{*}{ Solvent } & \multirow{2}{*}{ Extract } & \multicolumn{7}{c}{$\mathrm{LD}_{50} \mathrm{mg} / \mathrm{g}$ at different exposure time intervals $(\mathrm{h})$} \\
& & 0.5 & 6 & 12 & 24 & 36 & 48 & 60 & 72 \\
\hline Pet. ether & Leaves & 17.6 & 12.9 & 11.3 & 82.4 & 83.5 & 9.47 & 8.73 & 8.61 \\
\hline $\mathrm{CHCl}_{3}$ & Stem bark & - & 9.77 & 9.44 & 7.71 & 6.56 & 5.94 & 5.39 & 5.40 \\
\hline \multirow{2}{*}{$\mathrm{CH}_{3} \mathrm{OH}$} & Root & - & 19.5 & 19.1 & 17.5 & 16.7 & 16.2 & 15.8 & 15.9 \\
& Stem bark & - & 5.40 & 14.7 & 13.7 & 11 & 10.9 & 9.46 & 9.10 \\
\hline
\end{tabular}

\subsection{Dose mortality effects on T. castaneum}

The results of the fatal activity assays of the Pet. ether and $\mathrm{CH}_{3} \mathrm{OH}$ extracts of white mulberry against the adult beetles of $T$. castaneum are represented in Table 3 . In this case, the highest activity was found in Pet. ether extract of leaves after $72 \mathrm{~h}$ which gave $\mathrm{LD}_{50}$ value $525 \mathrm{mg} / \mathrm{cm}^{2}$.

Table 3. $\mathrm{LD}_{50}$ values of white mulberry extracts against $T$. castaneum.

\begin{tabular}{ccccccccc}
\hline \multirow{2}{*}{ Extract } & \multirow{2}{*}{ Solvent } & \multicolumn{6}{c}{$\mathrm{LD}_{50} \mathrm{mg} / \mathrm{cm}^{2}$ at different exposure time intervals $(\mathrm{h})$} \\
& & 6 & 12 & 24 & 36 & 48 & 60 & 72 \\
\hline \multirow{2}{*}{ Leaves } & Pet. ether & 0.93 & 0.826 & 0.691 & 0.623 & 0.567 & 0.532 & 0.525 \\
& $\mathrm{CH}_{3} \mathrm{OH}$ & 3.804 & 3.429 & 3.284 & 2.736 & 2.441 & 2.311 & 2.264 \\
\hline
\end{tabular}

According to intensity of activity the extracts of white mulberry could be arranged in the following descending order: leaves (Pet. ether) $>$ stem bark $\left(\mathrm{CHCl}_{3}\right)>$ stem bark $($ Pet. ether) > stem bark $\left(\mathrm{CH}_{3} \mathrm{OH}\right)>$ leaves $\left(\mathrm{CH}_{3} \mathrm{OH}\right)>\operatorname{root}($ Pet. ether $)>\operatorname{root}\left(\mathrm{CH}_{3} \mathrm{OH}\right)$ extracts. 


\section{Discussion}

The findings of the present investigation receive supports from the works done by previous researchers. Works on white mulberry extracts for insect mortality is scanty, however a lot of work have been done on antimicrobial activities. As in the investigation it reveals that ethanolic extracts of this plant has control potentials which gets support from Park et al. [19] who studied that mulberry extracts are rich in phytochemicals and have antimicrobial potential against harmful pathogens. In this study kuwanon $G$ was separated from methanolic extract of white mulberry and it showed antimicrobial activity with minimum inhibitory concentrations (MICs) of $8.0 \mu \mathrm{g} / \mathrm{mL}$ against Streptococcus mutans that is responsible for dental caries. In the experiment all the ethanolic extracts were found active which gets similarity with Ayoola et al. [20] who evaluated the antibacterial and antifungal activity of phytoconstituents isolated from the aqueous and ethanolic $(99.7 \% \mathrm{v} / \mathrm{v})$ extract of white mulberry. The study concluded that white mulberry extracts can be able to treat bacterial and fungal infections and these activities are due to the presence of phytochemicals, minerals. As we have found Pet. ether extract was very much active against all the insects this could get support from Jha and Shrivastava [21] who concluded that the whole plant is full of flavonoids like rutin, quercitrin, isoquercitrin and amino acids. Investigation was done on white mulberry for screening in vitro for antifungal activity. The findings of that investigation were an important step towards crop protection strategies for antifungal, antibacterial activity. Another findings in the same investigation reveals out from laboratory feeding tests on the development of Lymantria dispar L. larvae [21], which suggested that plants from the genus Morus were unsuitable for larval development and even indicated a high mortality of younger larvae and reduced feeding intensity by fifth instars' caterpillars; antifeeding activity, whether repellent or phagodeterrent, is probably based on a high content of glycosides. The findings were concluded that ethanol extract of white mulberry seed and leaf demonstrated a strong activity against gram positive, gram negative and fungi having strong pesticidal activity by Miller and Hanson [22]. According to Pelletier [23] over 250 glycosides have been isolated from white mulberry leaves, out of which nine belong to the group of deoxynojirimycin that was confirmed to have inhibitory effect on phytophagous larvae of Spodoptera frugiperda, also a member of the order Lepidoptera while in our investigation insects were from Lepidopteron groups the activity was because of the presence of same components. Similar results were presented by Pavela and Chermenskaya [24] in an experiment with 18 plant species, showing an absence of antifeeding effect of $A$. artemisiifolia on S. littoralis larvae. Plant-based pesticides (botanical pesticides or botanicals) have been in use as pesticides for over 150 years. It was only very recently that the synthetic insecticides effectively became the prominent agrochemicals for controlling all forms of agricultural pests and have assumed a very important position in the marketplace [25]. A flavonoid compound leanchianone $G$ isolated from root bark of $M$. alba showed significant antiviral activity against herpes simplex type 1 virus (HSV-1) by Du et al., [26] which supports our findings of the activity of root extract of the plant. 
Mechanisms of action of polyphenols mulberry extracts and related compounds as neuroprotectors in brain damage and aging was found by Rebai et al., [27] which is also active for brain disorder that can be effective for pest control which was revealed in our experiments. As the present investigation was carried on plant based pesticides or botanicals so it follows the traditional practice of pest control. While, all the three test insects are stored product pests and they cause a huge damage in stored products and ultimately causing economic damage, so the extracts of white mulberry can be used in the control of these stored product pests as these extracts showed mortality for those insect pests. Thus, plant-derived insecticides do not pose hazards of toxicity to humans and domestic animals, and are easily biodegraded compared to synthetic compounds, natural products are presumed to be safe for human [28]. This study was attempted to highlight white mulberry claimed to be used or associated with insect mortality activity, and it was found considerable.

\section{Conclusion}

Morus alba extracts collected in petroleum ether, chloroform and methanol tested against Callosobruchus chinensis, Sitophilus oryzae and Tribolium castaneum through residual film method to yield $\mathrm{LD}_{50}$ values depicted bioactive potentials of the test plant. Thus, further investigation is needed for total evaluation of this resource plant until the popular use of its potential leads is guaranteed.

\section{Acknowledgment}

The authors are grateful to the University Grants Commission (UGC) of Bangladesh. They would like to extend thanks to the Chairman, Department of Zoology, Rajshahi University, for providing laboratory facilities.

\section{References}

1. Anonymous, The Wealth of India (Raw Materials, CSIR, PID, New Delhi, 2001) 6(L-M) pp. 429-37.

2. S. Srivastava, R. Kapoor, A. Thathola, and R. P. Srivastava, Int. Food Sci. and Nut. 57(5-6), 305 (2006). https://doi.org/10.1080/09637480600801837

3. R. Singh, A. Bagachi, A. Semwal, S. Kaur, and A. Bharadwaj, Med. Plants Res. 7(9), 461 (2013).

4. L. N. Li, Pure Appl. Chem. 70(3), 547 (1998).

5. T. Nomura, T. Fukai, and G. Kuwanon, Chem. Pharm. Bull. 28, 2548 (1980). https://doi.org/10.1248/cpb.28.2548

6. M. S. Butt, A. Nazir, M. T. Sultan, and K. Schroen, Trends Food Sci. Technol. 19(10), 505 (2008). https://doi.org/10.1016/j.tifs.2008.06.002

7. F. Sun, L. M. Shen, and Z. J. Ma, Food Chem. 126, 1337 (2011). https://doi.org/10.1016/j.foodchem.2010.11.096

8. G. Chandra, Callosobruchus chinensis The Pulse Beetle Cowpea Bruchid (2014). IASZoology.com, Retrieved 28 November 2014.

9. L. K. Vats, Ind. J. Entomol. 36, 17 (1974). 
10. A. K. Raina, Ind. J. Entomol. 32(4), 303 (2013).

11. C. W. Beck and L. S. Blumer, A Handbook on Bean Beetles, Callosobruchus maculatus (National Science Foundation, 2014).

12. M. I. Bhuiyah, N. Islam, A. Begum, and M. A. Karim, Bang. J. Zool. 18, 67 (1990).

13. E. H. Smith and R. C. Whitman, NPCA Field Guide to Structural Pests (National Pest Management Association, Dunn Loring, Virginia, 1992).

14. K. Alanko, T. Tuomi, M. Vanhanen, M. Pajari-Backas, L. Kanerva, K. Havu, K. Saarinen, and D. P. Bruynzeel, Allergy 55(9), 879 (2000). https://doi.org/10.1034/j.1398-9995.2000.00572.x

15. N. E. Good, The Flour Beetles of the Genus Tribolium, $5^{\text {th }}$ Edition (USDA Technical Bulletin, 1936) pp. 27-28.

16. W. S. Abbott, Econ. Ento. 18(2), 265 (1925). https://doi.org/10.1093/jee/18.2.265a

17. D. J. Finney, Probit Analysis: A Statistical Treatment of the Sigmoid Response Curve (Cambridge University Press, London, 1947) pp. 333.

18. J. R. Busvine, A Critical Review of the Techniques for Testing Insecticides (Commonwealth Agricultural Bureaux, London, 1971) pp. 345.

19. K. M. Park, J. S. You, H. Y. Lee, N. I. Baek, J. K. Hwang, and G. Kuwanon, Entopharm. 84(23), 181 (2003).

20. O. A. Ayoolal, R. A. Baiyewul, J. N. Ekunolal, B. A. Olajirel, J. A. Egunjobil, E. O. Ayeni, and O. O. Ayodelel, Afr. Pharma. Pharmacol. 5(19), 2161 (2011). https://doi.org/10.5897/AJPP11.590

21. S. Jha and A. K. Srivastava, Int. Agri. Sci. Res. 3(1), 157 (2013).

22. J. C. Miller and P. E. Hanson, Laboratory Feeding Tests on the Development of Gypsy Moth Larvae with Reference to Plant Taxa and Allelochemicals (Agricultural Experiment Station, Oregon State University, 1994).

23. S. W. Pelletier, Alkaloids: Chemical and Biological Perspectives, $1^{\text {st }}$ Edition, (Pergamon, UK, 2001) Vol. 15, pp. 656

24. R. Pavela and T. Chermenskaya, Plant Protec. Sci. 4, 145 (2004).

25. J. Du, Z. D. He, R. W. Jiang, W. C. Ye, H. X. Xu, and P. P. H. But, Phytochem. 62, 1235 (2003). https://doi.org/10.1016/S0031-9422(02)00753-7

26. V. V. Oberemok, K. V. Laikova, Y. I. Gninenko, A. S. Zaitsev, P. M. Nyadar, and T. A. Adeyemi, Plant Protec. Res. 55(3), 221 (2015).

27. O. Rebai, M. Belkhir, S. Fattouch, and M. Amri, Applied Pharm. Sci. 7(1), 217 (2017).

28. H. Ali, S. Sabiha, S. Islam, S. B. Rekha, M. Nesa, and N. Islam, Pharmaco. Phytochem. 6(1), 466 (2017). 